Military Technical College Kobry El-Kobbah, Cairo, Egypt

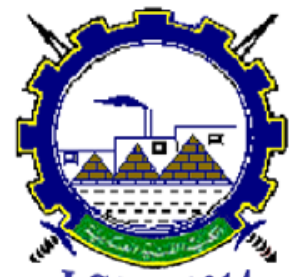

I.C.E.E.2014 $7^{\text {th }}$ International Conference

on

Chemical \& Environmental

Engineering

27 - 29 May, 2014.

\title{
CEEC-1
}

\section{Chemical Behavior And Corrosion Inhibition Of Zinc Electrode In Phosphate Solutions Under Open Circuit Conditions}

\author{
S. Abd El Wanees* and Y. Atef ${ }^{\dagger}$
}

\begin{abstract}
:
The electrochemical behavior of zinc electrode has been studied in different concentrations of $\mathrm{Na}_{3} \mathrm{PO}_{4} \cdot 12 \mathrm{H}_{2} \mathrm{O}$ solution using a simple potentiometric method. The study involves the measurement of the electrode potentials under open-circuit conditions. The potential was followed as a function of both time and $\mathrm{Na}_{3} \mathrm{PO}_{4} \cdot 12 \mathrm{H}_{2} \mathrm{O}$ solution concentration until the values of steady-state potential are obtained. The steady potential changed on the addition of increasing amounts of different aggressive anions due to the breakdown of passivity. The way of variation of the steady-state potentials of zinc electrode in aggressive solutions upon the addition of increasing quantities of some inhibitors as the type of inorganic inhibitors are also concerned. The potential shifts towards more positive values the addition of inhibitors and the potential curves recall those reported in aggressive anion-free solution indicating pitting corrosion. The micrograph of zinc surface in presence of different concentrations of aggressive ions was investigated using Scanning Electron Microscope SEM.
\end{abstract}

Keywords: Zinc, Sodium phosphate, corrosion, inhibitors and Potential time.

* Chemistry Department, Zagazig University, Zagazig, Egypt.

† Chemistry Administration, Cairo ${ }^{\dagger}$, Egypt. Present Address: jasy9@yahoo.com 


\section{Introduction}

Zinc metal is widely used as a high capacity anodic material for primary and secondary alkaline batteries in aqueous solution, e.g. alkaline $\mathrm{MnO}_{2} / \mathrm{Zn}$ and $\mathrm{Zn}$-carbon cells because of its high specific energy, low cost, abundance and non-toxicity. Zinc is used in a wide range of applications by various industries, e.g. as a construction material for roofs and facades in structural and civil engineering or as a sacrificial coating to protect iron and steel products from environmental corrosion attack in the steel producing and processing industry, especially the automotive industry [1,2]. Phosphate coatings are used on steel parts for corrosion resistance, lubricity, or as a foundation for subsequent coatings or painting. It serves as a conversion coating in which a dilute solution of phosphoric acid and phosphate salts is applied via spraying or immersion and chemically reacts with the surface of the part being coated to form a layer of insoluble, crystalline phosphates [3]. Phosphate conversions coatings can also be used on aluminium, zinc, cadmium, silver and tin [4].

However the high capacity of zinc anode can only be obtained in very concentrated alkaline solution. In dilute alkaline solutions, the discharge capacity and power capability of zinc anode decrease dramatically with decreasing $\mathrm{OH}$ - concentrations due to the passivation of zinc surface. The passivation of zinc anode in dilute alkaline solution is known to result from the formation of passive film on zinc surface. In past decades, numerous works have been undertaken to evaluate the anodic passivation mechanism and the properties of the passive film of zinc electrode in alkaline solution [5-9].

The corrosion reactions leading to hydrogen evolution involve electrochemical active sites on the zinc anode surface. Such sites can include surface and bulk metal impurities, surface lattice features, grain boundary features, lattice defects, point defects and inclusions. In order to minimize undesirable corrosion and gassing, efforts are made in order to reduce the presence of impurities in the anode and the electrolyte as well as employing corrosionresistant zinc or zinc alloys.

Inhibiting agents are added in order to improve the electrochemical behavior of the discharged cell, decrease in the ohmic cell resistance and decrease in the self-discharge rate while the cell is being partially discharged, and to suppress the anodic reaction of zinc, still there is a need to add another component to the electrolyte which is capable of reducing the zinc corrosion in the alkaline media. Both of corrosion and inhibition processes involve a decrease in free energy of the metal/solution interface as any physicochemical process can occur at low free energy between the metal and its environment and the suggesting process that associated with a larger decrease in free energy [10, 11]. Organic surfactants and inorganic corrosion-inhibiting agents are commonly added to the zinc anode. The role of these organic additives is to form hydrophobic film that protects the zinc anode surface forming efficient anode-electrolyte interface. The efficiency of these compounds to enhance the corrosion resistance of zinc depends on their chemical structure, concentration and their stability in the electrolyte.

In view of this, we have produced a $\mathrm{Zn}$ metal and aimed to investigate corrosion behavior depending on $\mathrm{Na}_{3} \mathrm{PO}_{4} \cdot 12 \mathrm{H}_{2} \mathrm{O}$ alkaline solution using the conventional potential time method. The effect of different aggressive anions is also investigated and devoted to determine the minimum concentration of the inhibitive anions that can withstand a certain concentration of an aggressive anion. 


\section{Experimental}

The simple electrode vessel of the zinc electrode made of Pyrex glass, has an inlet and outlet for oxygen and could accommodate a volume of about $50 \mathrm{ml}$ of the test solution. The vessel is provided with a small salt bridge which was filled with the solution under test and dipped into a small beaker containing a portion of the same solution. In the same beaker the salt bridge is connected to the reference half cell, saturated calomel electrode (S.C.E) and both working and saturated calomel electrodes are connected by a device for measuring the voltage as a function of time. In this matter contamination of the test solution by the $\mathrm{Cl}^{-}$ions of the reference electrode during the span of the experiment was practically nullified. The E.M.F of the cell: $(+)$ saturated calomel electrode/ electrolyte/ zinc electrode () was measured on an electronic Digital Multimeter (Escort, EDM - 2116) to the nearest $\mathrm{mV}$. The steady state potentials were considered valid when values obtained not changing more than $1 \mathrm{mV} / 5$ minutes.

Measurements were carried out mainly at $25 \pm 0.1^{\circ} \mathrm{C}$. To investigate effect of the pitting corrosion anions, viz, $\mathrm{Cl}^{-}, \mathrm{Br}^{-}, \mathrm{S}^{2-}, \mathrm{ClO}_{4}^{-}, \mathrm{ClO}_{3}{ }^{-}$on the stability of the passive nature of $\mathrm{Zn}$ electrode, two different procedures were used. Zinc electrode was firstly immersed in the solution of sodium phosphate of definite concentration; the change in the potential was followed as a function of time until steady-state potential value was established. In the second procedure, the zinc electrode was equilibrated in a definite volume of sodium phosphate solutions of definite concentration to which enough corrosive (or inhibiting) agents was introduced until a steady-state potential was established. Then increasing amounts of the aggressive/ or inhibiting salts were successively added to the same phosphate solution, allowing always sufficient time for the establishment of a constant steady-potential after each addition.

\section{Results and discussion}

\subsection{Variation of the potential of zinc electrode with time in sodium phosphate solutions:}

The study involves the variation of potential of the zinc electrode as a function of time in normally aerated sodium phosphate solutions of concentration range from $5 \times 10^{-4}$ to $5 \mathrm{x}$ $10^{-1} \mathrm{M}$, as shown in Fig. (1). In lower concentrations of sodium phosphate solution, the potential is shifted directly from more negative values towards less negative values and attained constancy and after short time, the potential falls quickly to negative values till it reaches a constant value (steady state potential). The ennobling of the zinc electrode potential when immersed in phosphate solutions of concentrations $\leq 1 \times 10^{-3} \mathrm{M}$, denotes that the preimmersion air-formed metal oxide film is not sufficient to impart long time passivity. In concentration range from $5 \times 10^{-3}$ to $8 \times 10^{-2} \mathrm{M}$ of sodium phosphate solution , the potential is shifted directly from more negative values towards less negative values and attained a constancy after 60-70 minutes (steady state potential) without the potential falling. In higher concentrations as 0.1 and $0.5 \mathrm{M}$ of sodium phosphate solutions, the potential is shifted directly from less negative values towards more negative values and reached to constancy. Hence, the zinc electrode potential depends on the concentration of sodium phosphate solution, also steady state potential, Fig. (2).

The simplified model used to predict theoretically the electrochemical behavior of pure zinc in alkaline media does not take into account the strong kinetic influence of the compositional and structural changes in the precipitate layer. An insight into the reaction mechanism for developing an advanced model of the behavior of zinc in alkaline media with changing $\mathrm{pH}$ had been given, [12]. It represents the theoretical potential behavior following 
the electrochemical reaction path regarding hydroxylation at the interface and thermodynamical aspects $[13,14]$.

$$
\begin{aligned}
& \mathrm{Zn}-2 \mathrm{e}^{-} \rightarrow \mathrm{Zn}^{+2} \\
& \mathrm{Zn}^{+2}+2 \mathrm{OH}^{-} \rightarrow \mathrm{Zn}(\mathrm{OH})_{2} \\
& \mathrm{Zn}(\mathrm{OH})_{2}+\mathrm{OH}^{-} \rightarrow \mathrm{ZnO}_{2}{ }^{-}+\mathrm{H}_{2} \mathrm{O}
\end{aligned}
$$

\subsection{Variation of the open circuit electrode potential of $\mathrm{Zn}$ in sodium phosphate in absence and presence of the aggressive anions:}

The second part of the work is devoted to determine the concentrations of the aggressive anions that can withstand the higher potential period of a certain concentration of sodium phosphate using a simple potentiometric method.

The investigation involves adding of some corrosive anions such as $\mathrm{Cl}^{-}, \mathrm{Br}^{-}, \mathrm{ClO}_{4}^{-}$, $\mathrm{ClO}_{3}{ }^{-}, \mathrm{S}^{2-}$ to throw light on the behavior of the $\mathrm{Zn}$ electrode in different media. The potential was followed as a function of time in different concentrations of the corrosive solutions till steady values were established, showing in Figs. (3-7). By increasing the concentration of the aggressive salts more than $1 \times 10^{-2} \mathrm{M}$, the potential of zinc electrode is shifted towards more negative values with the occurrence of marked corrosion. Healing and further thickening of the film continue in the solutions until steady-state is attained. It is clear from the curves of Figs. (3-7) that the anions of these groups promote the corrosion of zinc and the extent of corrosion promotion increases with the anion content of the solution.

Moreover, at one and the same concentration of the different anions, it is obvious that the extent of corrosion promotion is dependent on the type of anion in the solution. To determine the minimum concentration of an aggressive anion that can be tolerated by a certain concentration of the sodium phosphate solution $\left(1 \times 10^{-3} \mathrm{M}\right)$, the steady potential of the $\mathrm{Zn}$ electrode in the sodium phosphate solution of a certain concentration was awaited for. It is concluded therefore that, the cathodic process predominates over the anodic ones, through either an increase in the self-polarization of the anodic areas or a decrease in the selfpolarization of the cathodic ones $[15,16]$. The corrosivity of the anions, as judged by values increases in the order $\mathrm{Cl}^{-}>\mathrm{Br}^{-}$. The effect of $\mathrm{Cl}^{-}$anion is higher than $\mathrm{Br}^{-}$anion solution, consequently, more corrosive [15]. The corrosivity of the above anions increases in the same order:

$$
\mathrm{Na}_{2} \mathrm{~S}>\mathrm{NaCl}>\mathrm{NaBr}>\mathrm{NaClO}_{4}>\mathrm{NaClO}_{3}
$$

The plot of the steady-state potentials as a function the logarithm of the molar concentration of these anions is shown in Fig (8). Straight lines were obtained which fulfill Brasher's equation [17].

$$
\mathrm{E}=\mathrm{a}-\mathrm{b} \log \mathrm{C}
$$

where $\mathrm{a}$ and $\mathrm{b}$ are constants.

From these measurements, potential-weight curves could be constructed for solutions of different concentrations of corrosive agent. Also, a small weighed quantity of $\mathrm{NaCl}, \mathrm{NaBr}$, $\mathrm{NaClO}_{4}, \mathrm{NaClO}_{3}$ and $\mathrm{Na}_{2} \mathrm{~S}$ was then added and the variation of the potential with time was followed until constancy, as another application to prove the corrosivity of these anions. New quantities were further introduced and the establishment of steady potential was ensured. The type of corrosion always occurs under the influence of the presence of both the inhibitive and corroding anions is of the localized type, the extreme of which is pitting corrosion $[18,19]$. When this was reached a weighed quantity of the aggressive salt was added and a constant potential was again left to be attained. Then other quantities of the salt were introduced and in each case the electrode was left to acquire a steady potential. The results of this set of 
measurements on the sodium phosphate solution of different weights to which $\mathrm{NaCl}, \mathrm{NaBr}$, $\mathrm{NaClO}_{4}, \mathrm{NaClO}_{3}$ and $\mathrm{Na}_{2} \mathrm{~S}$ was added are shown by the curves of Fig (9). These curves represent the variation of the steady-state potential of the $\mathrm{Zn}$ electrode with the total weight of the aggressive salt in solution. The potential of the zinc electrode was measured as a function of time in solutions of the sodium phosphate, until steady-state values established. The concentration of each anion was varied between 0.01 and $0.3 \mathrm{M}$ and the solutions were strongly aerated. It is obvious that the extent of corrosion promotion is dependent on the type of the anions in the solution.

The corrosivity of the above anions increases in the same order. It is of interest to note that similar finding were reported for most of the corrosive inorganic anions $[15,17,20,21$, 22]. Brasher [17] assumes that the shift of the $\mathrm{Zn}$ electrode potential towards active value is the result of an altered balance between the anodic and the cathodic areas set up by the competing influence of oxide-film-repair by oxygen.

The presence of the aggressive ions shifts the $E_{s t}$ into more negative values i.e. weakness of the passive film formed on Zn surface takes place and the potential is shifted into the negative (active) direction to values which are more active, the higher the aggressive ions content of the solution. It is quite clear that the aggressive ions do not attack the passive film at any concentration but only a certain concentration is required for initiation of corrosion. The steady-state potential of the Zn electrode changes from the value measured in aggressive ion-free solutions to more active values. The type of corrosion occurring under such conditions is always of the pitting type and visible pits could be seen by the naked eyes on the metal surface.

Figure (10) shows SEM micrograph examination of the zinc surface after immersion in a solution of $0.05 \mathrm{M}$ sodium phosphate containing $0.5 \mathrm{M} \mathrm{NaCl}$, for a period of 80 minutes. It is clear that, the metal surface shows a large number of fine pits in presence of $\mathrm{Cl}^{-}$ions. The pits have large volume due to formation of well-defined pits with the propagation of pitting corrosion and the corrosion products inside the pit shown.

\subsection{Variation of the open circuit electrode potential of $\mathrm{Zn}$ in sodium phosphate containing aggressive ions in absence and presence of passivators:}

The third investigation shows the variation of the open circuit electrode potential of $\mathrm{Zn}$ in $1 \times 10^{-3} \mathrm{M}$ sodium phosphate solutions containing $0.03 \mathrm{M} \mathrm{NaCl}$ in absence and presence of passivators. The potential was followed as a function of time in different concentrations of the inhibitor solutions till steady values were established. The curves of Figs (11-13) represent the effect of addition of some inorganic salts namely $\mathrm{Na}_{2} \mathrm{~B}_{4} \mathrm{O}_{7}, \mathrm{Na}_{2} \mathrm{WO}_{4}$ and $\mathrm{Na}_{2} \mathrm{CrO}_{4}$, respectively, as passivators for the corrosion of zinc in $1 \times 10^{-3} \mathrm{M}$ sodium phosphate solutions, at $25{ }^{\circ} \mathrm{C}$. The addition of these additives causes the potential to shift directly from more negative values towards less negative values. The steady-state potential is reached from negative values and becomes nobler than the steady-state potential in passivator-free solution, with increasing the additives concentration. This behavior signifies thickening of the oxide film on the surface of the metal. Shams El Din and Khedr [15] showed that chromate and nitrite promote or stifles the corrosion of Zn depending on their concentrations as the example of the inorganic inhibitors. Some outhers using open circuit potential to study corrosion. The effect of some organic inhibitors, namely, (acridine, benzyl quinolinium chloride, dodecyl quinolinium-bromide, tributyl benzyl ammonium iodide and potassium iodide) had been studied using open circuit potential [23]. 
It is shown from the inhibition process that it occurred when associated with lower free energy than that was in the corrosion process. The decrease in free energy associated with this reaction could be attributed to the specific adsorption of these anions [24, 25] and the reaction of electrostatic fields through the oxide between opposite charges [26]. In addition, the inhibiting anions also make film-repair as in case of $\mathrm{CrO}_{4}{ }^{2-}$ and $\mathrm{NO}_{2}{ }^{-}[27,28]$ or by blocking the active sites on the metal surface as with benzoate [10].

The variation of the steady-state potential of zinc with the logarithm of the molar concentration of the inorganic additives, $\mathrm{C}_{\mathrm{add}}\left(\mathrm{Na}_{2} \mathrm{~B}_{4} \mathrm{O}_{7}, \mathrm{Na}_{2} \mathrm{WO}_{4}\right.$ and $\left.\mathrm{Na}_{2} \mathrm{CrO}_{4}\right)$ is shown in Fig (14). Straight lines were obtained satisfying the equation:

$$
E_{\mathrm{st}}=\alpha_{1}+\beta_{1} \log \mathrm{C}_{\mathrm{add}}
$$

where $\alpha_{1}$ and $\beta_{1}$ are constants depending on the nature of the metal and the type of the used anions.

This behavior could be explained on the basis of increasing the inhibiting action of the additive. On the other hand in $1 \times 10^{-3} \mathrm{M} \mathrm{Na}_{3} \mathrm{PO}_{4} .12 \mathrm{H}_{2} \mathrm{O}$ with $0.03 \mathrm{M} \mathrm{NaCl}$ solution and the different concentrations for different inhibitors are depending on the type of the inorganic additives. Thus one can arrange the efficiency of these compounds according to their addition in the ennobling of the steady-state potential which increased in the following order for inorganic additives:

$$
\mathrm{Na}_{2} \mathrm{CrO}_{4}>\mathrm{Na}_{2} \mathrm{WO}_{4}>\mathrm{Na}_{2} \mathrm{~B}_{4} \mathrm{O}_{7}
$$

\section{Conclusions}

From the chemical behavior of zinc electrode in aqueous solution under open circuit conditions, increasing the concentrations of sodium phosphate shifts the steady-state of $\mathrm{Zn}$ electrode potential, $E_{s t}$, towards more negative values denoting oxide film destruction. The variation in the steady-state potential, $E_{s t}$, with the logarithm of the molar concentration of phosphate anions, $\mathrm{C}$, follow the relation: $\mathrm{E}_{\mathrm{st}}=\alpha-\beta \log \mathrm{C}$, where $\alpha$ and $\beta$ are constants.

The presence of increasing concentrations of the aggressive ions shifts the $E_{\text {st }}$ into the negative (active) direction to values which are more active, the higher the aggressive ion content of the solution.

In presence of increasing concentrations of $\mathrm{Na}_{2} \mathrm{~B}_{4} \mathrm{O}_{7}, \mathrm{Na}_{2} \mathrm{WO}_{4}$ and $\mathrm{Na}_{2} \mathrm{CrO}_{4}$, as inorganic inhibitors for the corrosion of zinc in sodium phosphate solutions, $\mathrm{E}_{\text {st }}$ becomes nobler than that of passivator-free solution. This behavior is signifying the thickening of the oxide film on $\mathrm{Zn}$ surface. Plotting the values of $\mathrm{E}_{\mathrm{st}}$ with the logarithm of the molar concentration, $\mathrm{C}_{\mathrm{add}}$, of the additives, inorganic passivators give straight lines, satisfying the relation: $E_{\mathrm{st}}=\alpha_{1}+\beta_{1} \log C_{\mathrm{add}}$, where $\alpha_{1}$ and $\beta_{1}$ are constants depending on the nature of the metal and type of anions used. The passivity increases of the $\mathrm{Zn}$ electrode as in the order: $\mathrm{Na}_{2} \mathrm{CrO}_{4}>\mathrm{Na}_{2} \mathrm{WO}_{4}>\mathrm{Na}_{2} \mathrm{~B}_{4} \mathrm{O}_{7}$.

\section{References}

[1] F.M. Androsch, K. K€osters, K.-H. Stellnberger, Stahl Eisen 121 (2001) 37.

[2] A.R. Marder, Prog. Mater. Sci. 45 (2000) 191.

[3] Dufour, Jim (2006). An Introduction to Metallurgy, 5th ed. Cameron. pp. IX 11-12.

[4] Edwards, Joseph (1997). Coating and Surface Treatment Systems for Metals. Finishing Publications Ltd. and ASM International. pp. 214-217.

[5] T.P. Dirkse, D.D. Wit, R. Shoemaker, J. Electrochem. Soc. 115 (1968) 442.

[6] R.W. Powers, M.W. Breiter, J. Electrochem. Soc. 116 (1969) 719. 
[7] T.P. Dirkse, N.A. Hampson, Electrochim. Acta 16 (1971) 2049.

[8] P.L. Cabot, M. Cortes, F.A. Centellas, J.A. Garrido, E. Perez, J. Electroanal. Chem. 201 (1986) 85.

[9] P.L. Cabot, M. Cortes, F.A. Centellas, E. Perez, J. Appl. Electrochem. 23 (1993) 371.

[10] Shams El-Din, A.M. and Abd El-Haleem, S.M., Werkstoffe Korros., 25, 571 (1974).

[11] Abd El Haleem, S.M. and Abd El Aal, A., J. Chem. Soc., Japan, 53 (1980).

[12] Stephan Bonk, Mariusz Wicinski, Achim Walter Hassel and Martin Stratmann, Electrochemistry Communications, 6, 800-804 (2004).

[13] Sato, N. in: N. Sato (Ed.), Electrochemistry at Metal and Semiconductor Electrodes, Elsevier Science, Amsterdam, 1998 (Chapter 5.11.1).

[14] De Zoubov, N. and Pourbaix, M. in: M. Pourbaix (Ed.), Atlas of Electrochemical Equilibria, National Association of Corrosion Engineers, 1974 (Chapter 15.1).

[15] Shams El-Din, A.M. and Khedr, M.G.A., Corros. Sci., 12, 393 (1972).

[16] Evans, U.R. "An Introduction to Metallic Corrosion" Ed. Arnold, London (1963) P. 65.

[17] Brasher, D.M., Nature, Lond., 193, 862 (1962).

[18] Brasher, D.M., Beymen, J.G., Mercer, A.D. and Rhoades-Brown, J.E., Proc. $2^{\text {nd }}$ Eur. Symp. on Corrosion Inhibition, 61 (1965).

[19] Milazzo, G., Electrochemistry, Elsevier Pnb. Co., P. 208 (1963).

[20] Gouda, V.K., Khedr, M.G.A. and Shams El-Din, A.M., Corros. Sci., 7, 221 (1967).

[21] Engell, H.J. and Stolica, N.D., Z. Physik. Chem., 20, 113 (1959).

[22] Gouda, V.R. and Sayed, S.M., Br. Corros. J., 8, 71 (1973).

[23] Abd El Rehim, S.S., Abd El Wahab, S.M. and Abd El Meguid, E.A., Surface and Coating Technology, 29, 325 (1986).

[24] Kabanov, B., Burstien, R. and Frumkin, A., Discuss. Farady, Soc., No.1, 259 (1947).

[25] Hickling, A., Trans. Farady, Soc., 41, 333 (1945).

[26] Hoar, T.P., Mears, D. and Rothwell, G., Corros. Sci., 5, 279 (1965).

[27] Mercer, A.D., Jenkins, I.R. and Brown, J.E., Br. Corros. J., 3, 136 (1968).

[28] Brasher, D.M., Rachenberg, D.R. and Mercer, A.D., Br. Corros. J., 3, 144 (1968). 


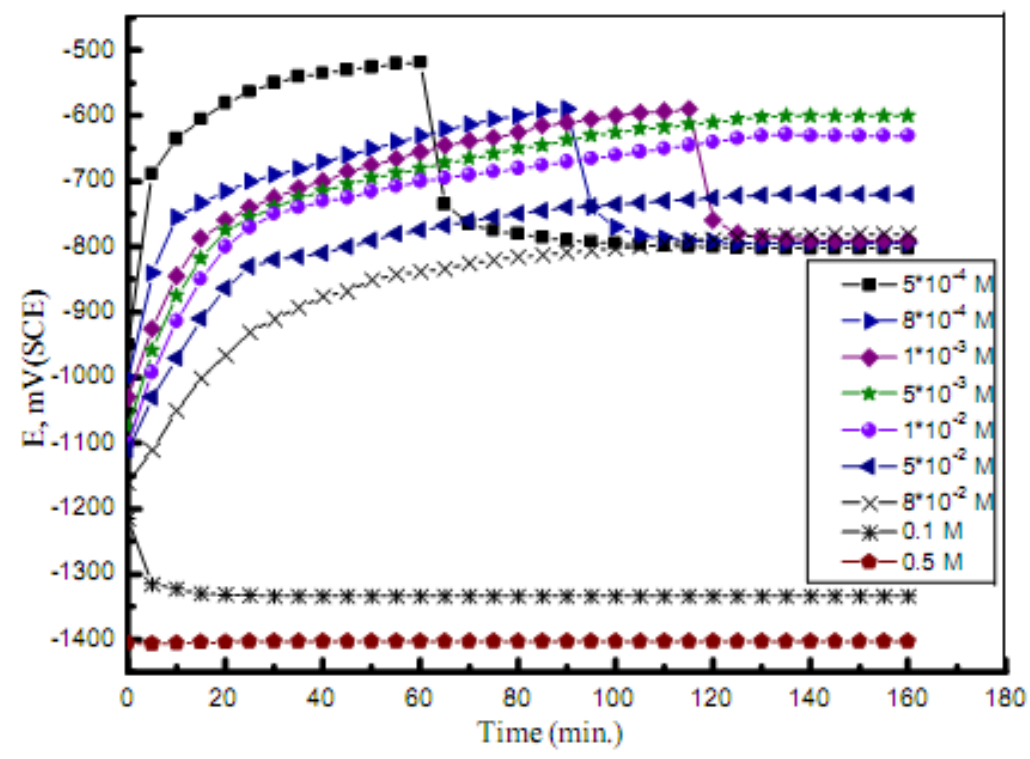

Fig. 1. The variation of the potential of zinc electrode with time in different concentrations of $\mathrm{Na}_{3} \mathrm{PO}_{4} \cdot 12 \mathrm{H}_{2} \mathrm{O}$, at $25{ }^{\circ} \mathrm{C}$.

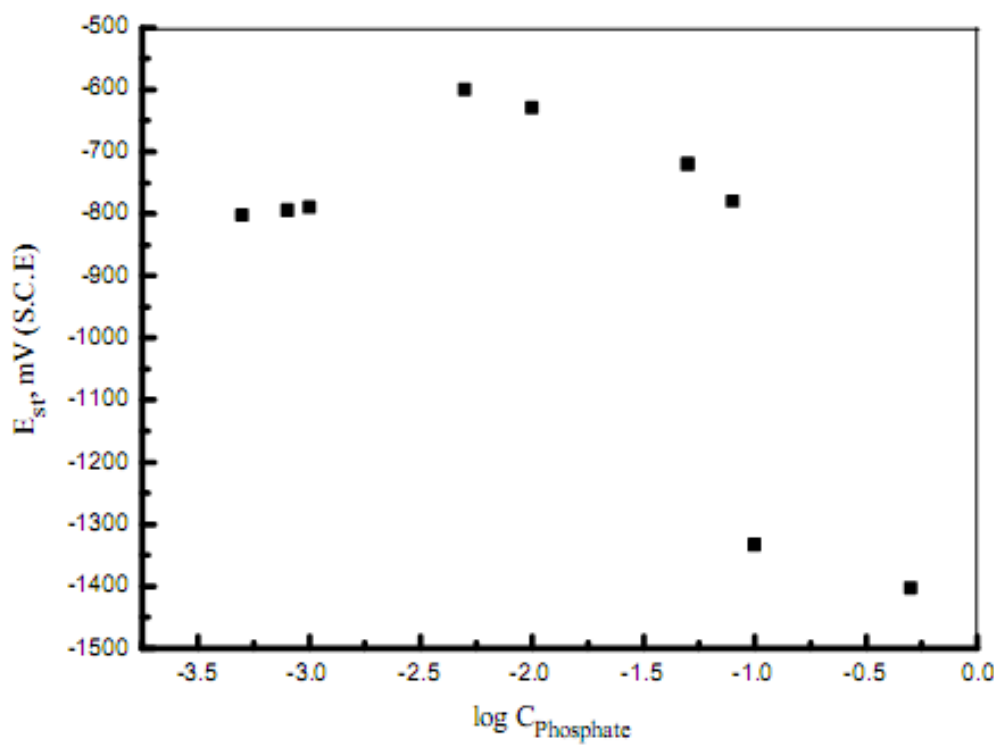

Fig. 2. Variation of steady state potential, $E_{s t}$ of zinc electrode with the logarithmic concentration of sodium phosphate, at $25^{\circ} \mathrm{C}$. 


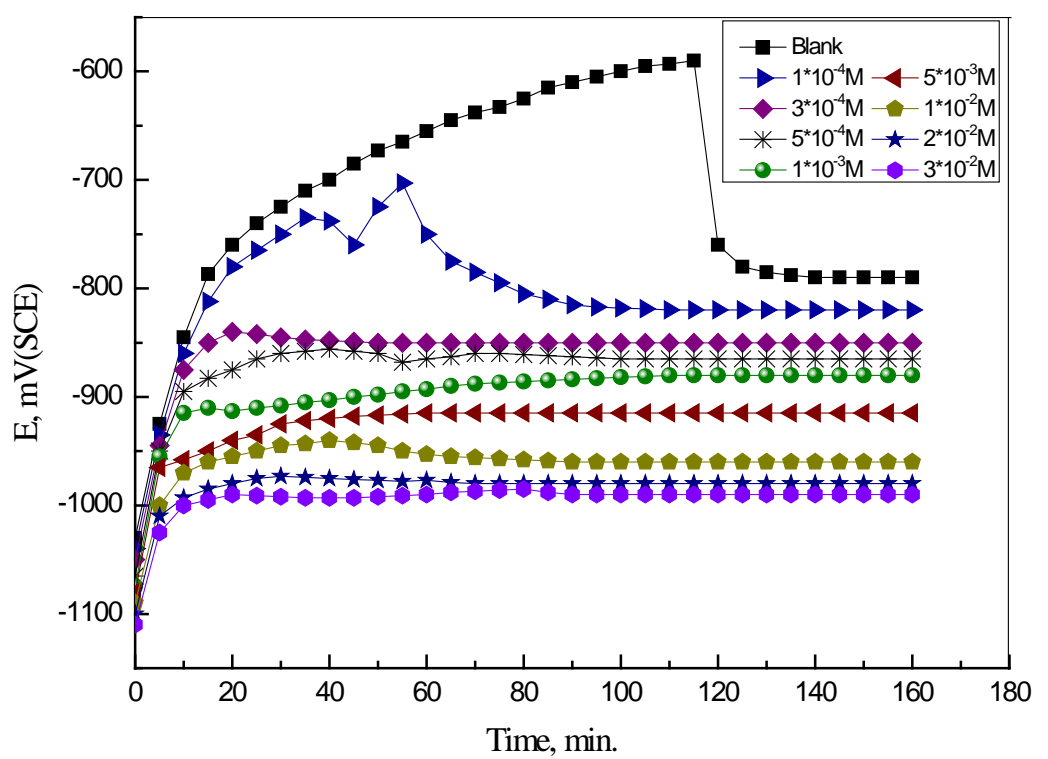

Fig. 3. The variation of the potential of zinc electrode in $1 \times 10^{-3} \mathrm{M} \mathrm{Na}_{3} \mathrm{PO}_{4} \cdot 12 \mathrm{H}_{2} \mathrm{O}$ with time in absence and presence of different concentrations of $\mathrm{NaCl}$, at $25{ }^{\circ} \mathrm{C}$.

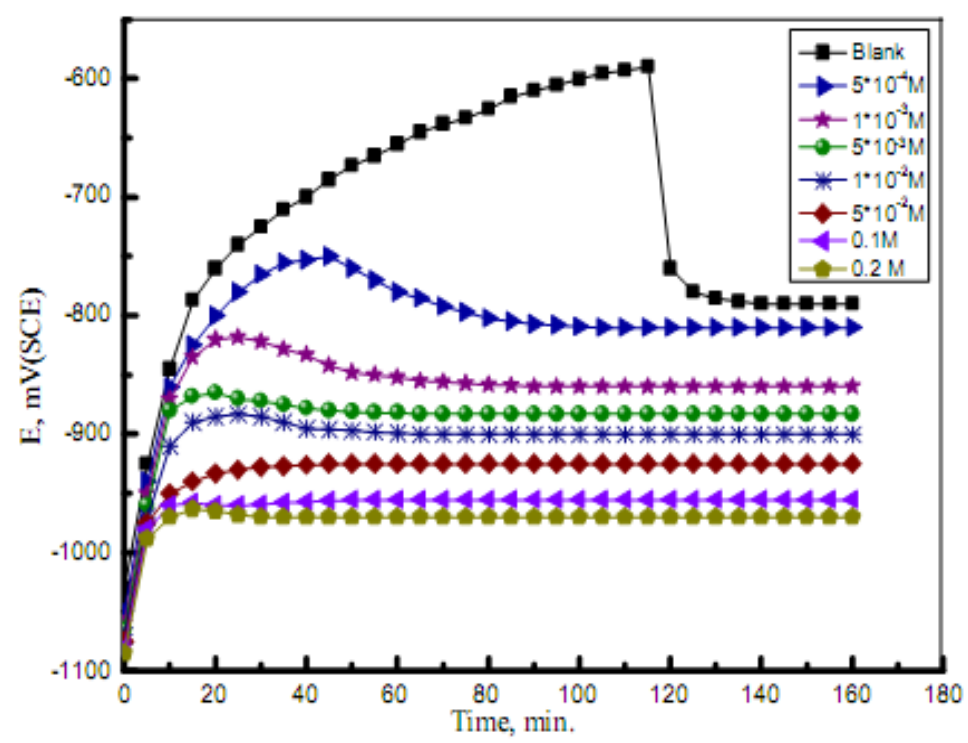

Fig. 4. The variation of the potential of zinc electrode in $1 \times 10^{-3} \mathrm{M} \mathrm{Na}_{3} \mathrm{PO}_{4} \cdot 12 \mathrm{H}_{2} \mathrm{O}$ with time in absence and presence of different concentrations of $\mathrm{NaBr}$, at $25^{\circ} \mathrm{C}$. 


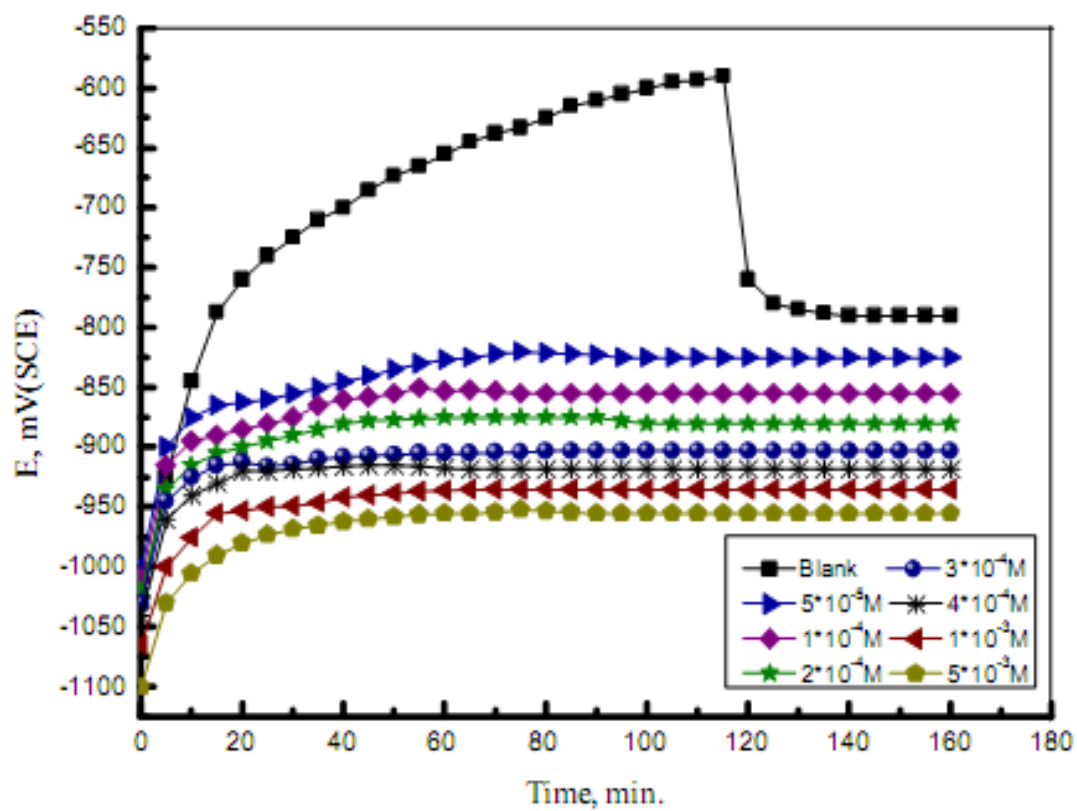

Fig. 5. The variation of the potential of zinc electrode in $1 \times 10^{-3} \mathrm{M} \mathrm{Na} \mathrm{PO}_{4} \cdot 12 \mathrm{H}_{2} \mathrm{O}$ with time in absence and presence of different concentrations of $\mathrm{Na}_{2} \mathrm{~S}$, at $25^{\circ} \mathrm{C}$.

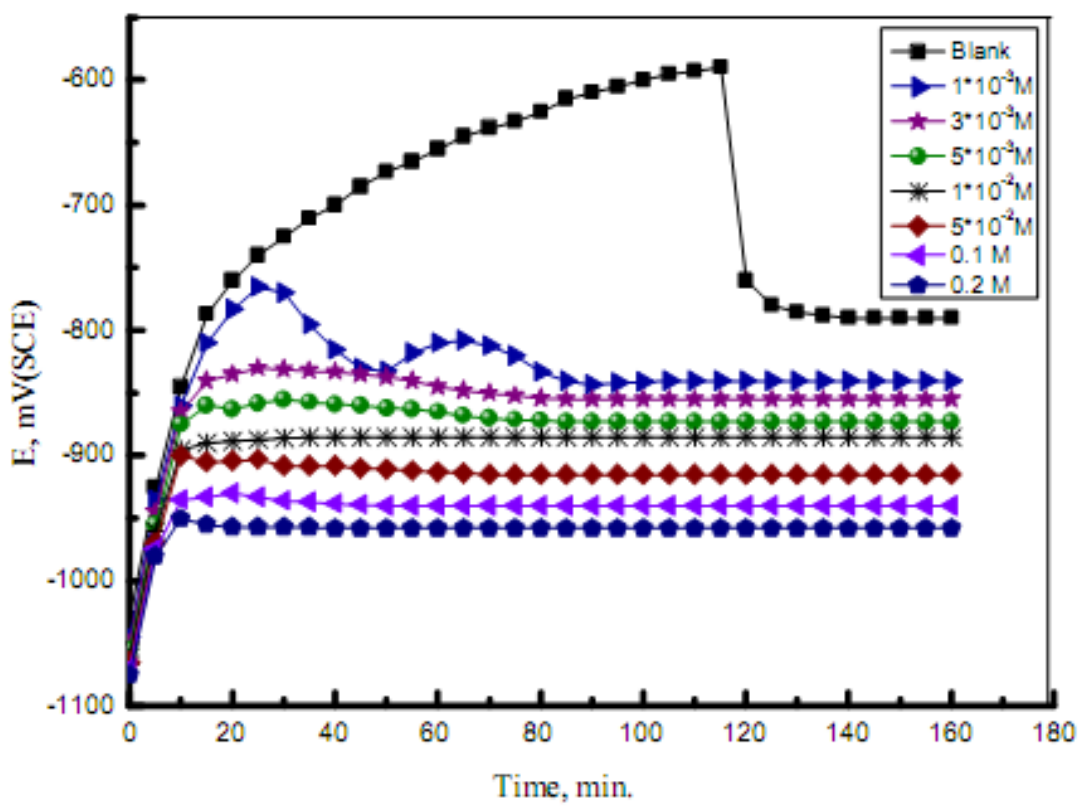

Fig. 6. The variation of the potential of zinc electrode in $1 \times 10^{-3} \mathrm{M} \mathrm{Na}{ }_{3} \mathrm{PO}_{4} \cdot 12 \mathrm{H}_{2} \mathrm{O}$ with time in absence and presence of different concentrations of $\mathrm{NaClO}_{4}$, at $25^{\circ} \mathrm{C}$. 


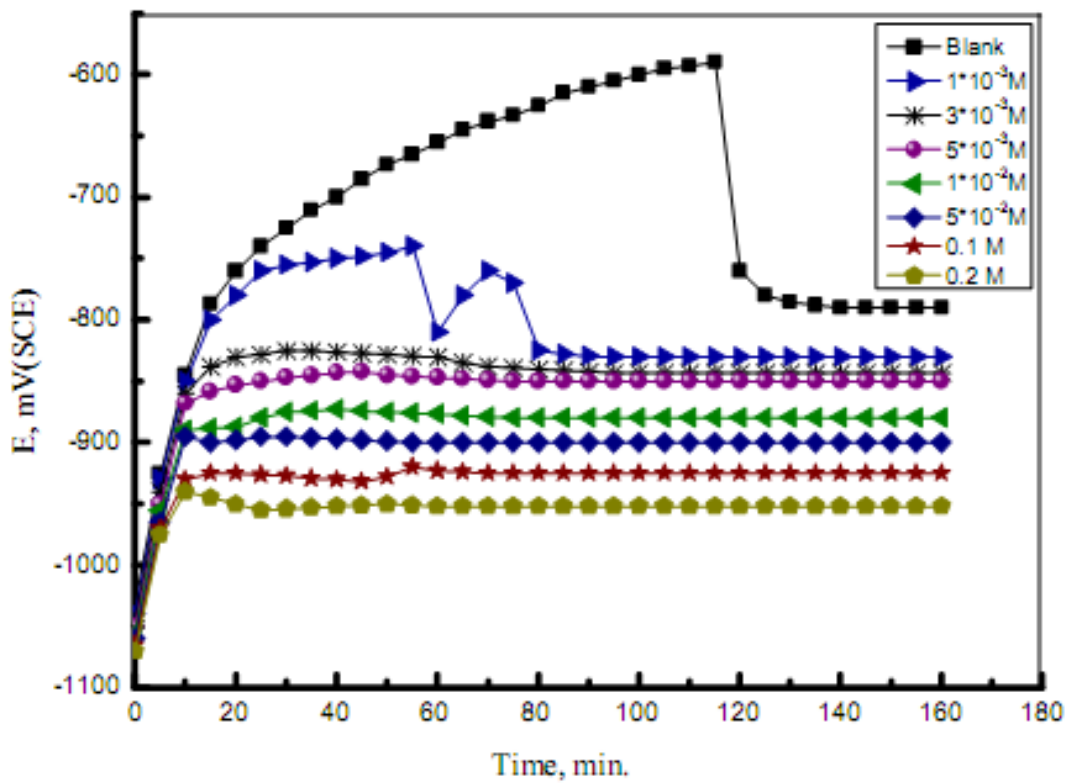

Fig. 7. The variation of the potential of zinc electrode in $1 \times 10^{-3} \mathrm{M} \mathrm{Na}_{3} \mathrm{PO}_{4} \cdot 12 \mathrm{H}_{2} \mathrm{O}$ with time in absence and presence of different concentrations of $\mathrm{NaClO}_{3}$, at $25{ }^{\circ} \mathrm{C}$.

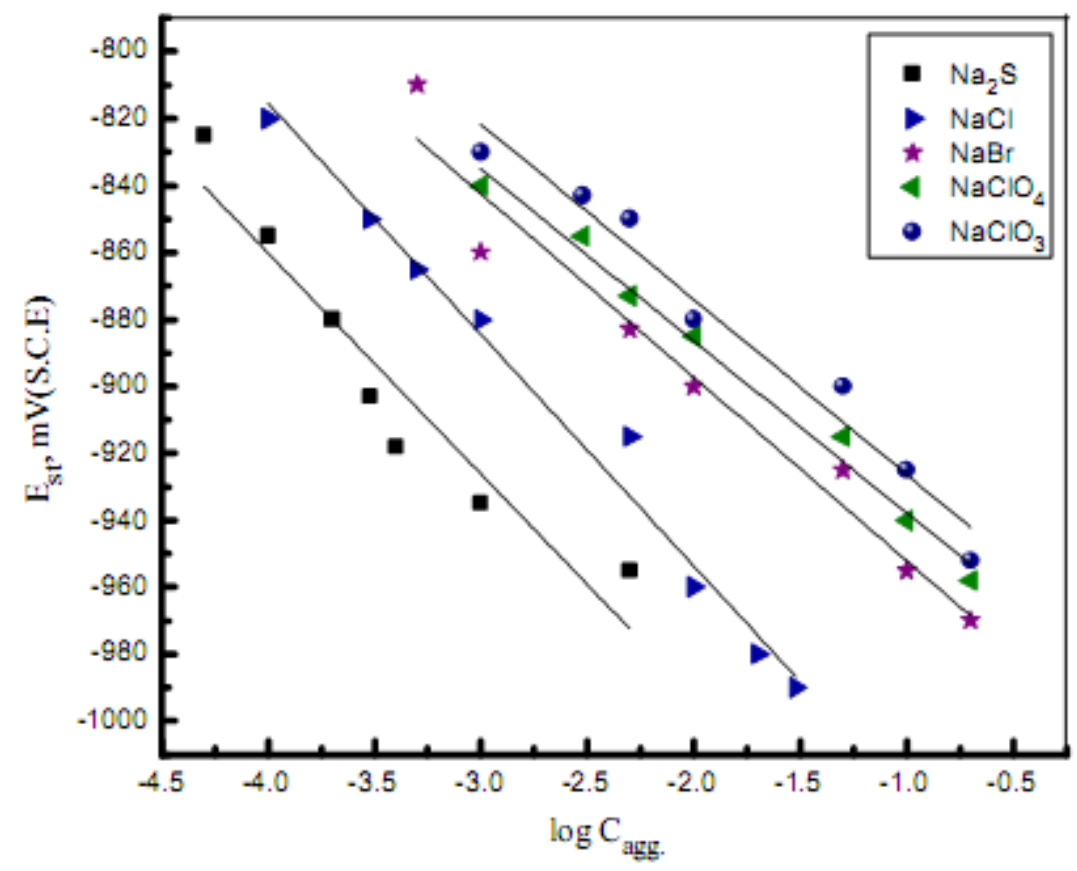

Fig. 8. Variation of steady state potential, $\mathrm{E}_{\mathrm{st}}$ of zinc electrode with the logarithmic concentration of aggressive anions in $1 \times 10^{-3} \mathrm{M} \mathrm{Na}_{3} \mathrm{PO}_{4} \cdot 12 \mathrm{H}_{2} \mathrm{O}$ solutions, at $25{ }^{\circ} \mathrm{C}$. 


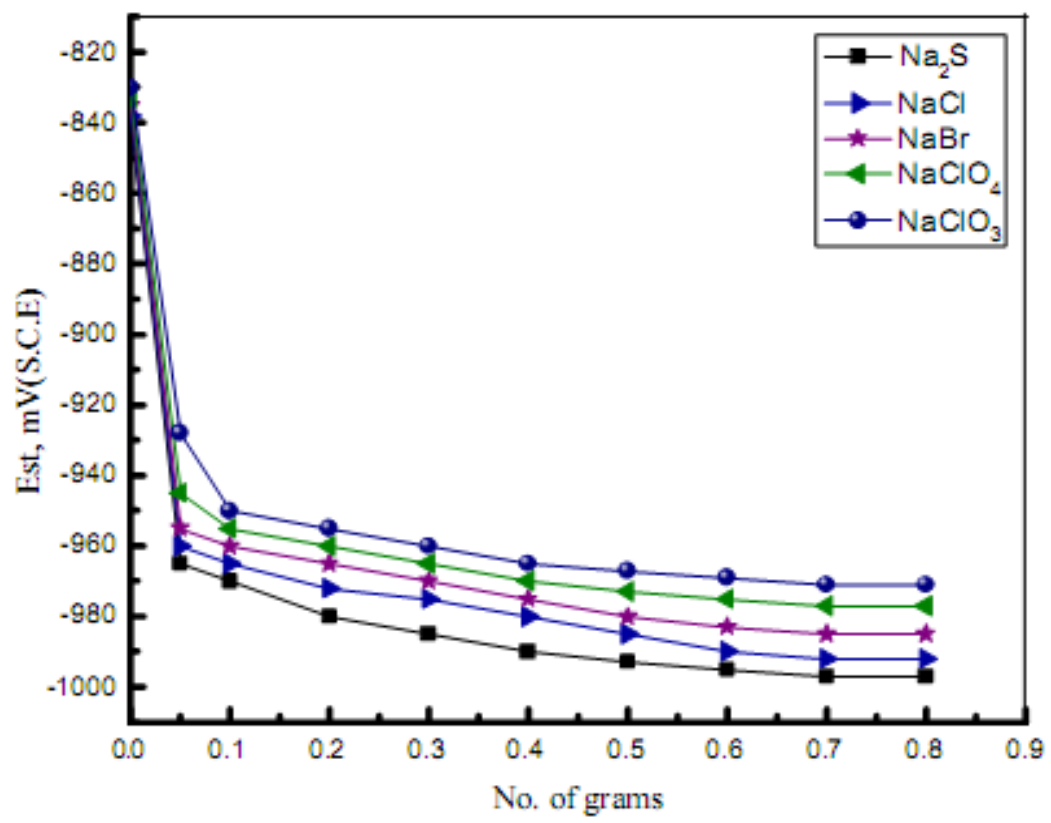

Fig. 9. Variation of $E_{s t}$ of zinc electrode with the number of grams added on $1 \times 10^{-3} \mathrm{M}$ sodium phosphate, at $25{ }^{\circ} \mathrm{C}$.

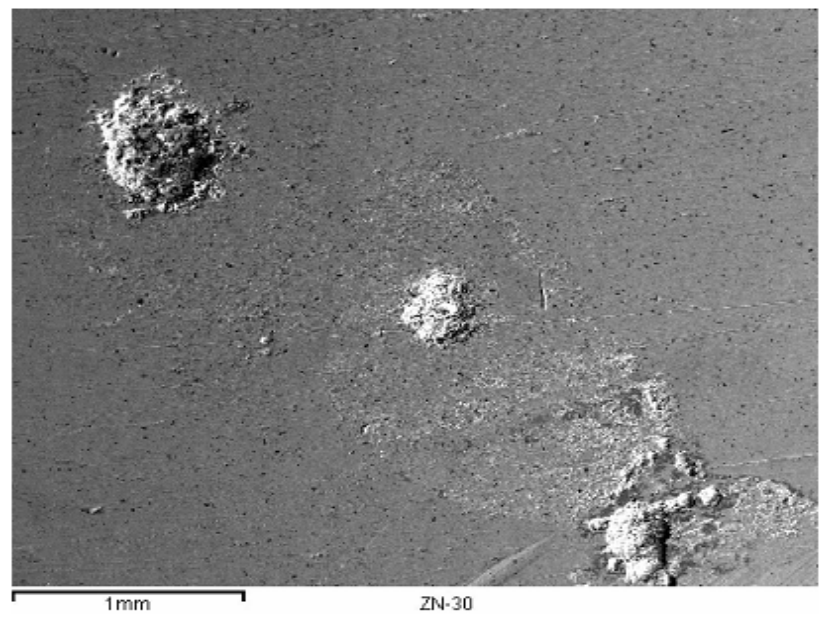

Fig. 10. SEM micrograph of Zn surface after immersion for a period of 80 minutes, at $25^{\circ} \mathrm{C}$, in a solution of $0.05 \mathrm{M}$ sodium phosphate containing $0.5 \mathrm{M} \mathrm{NaCl}$. 


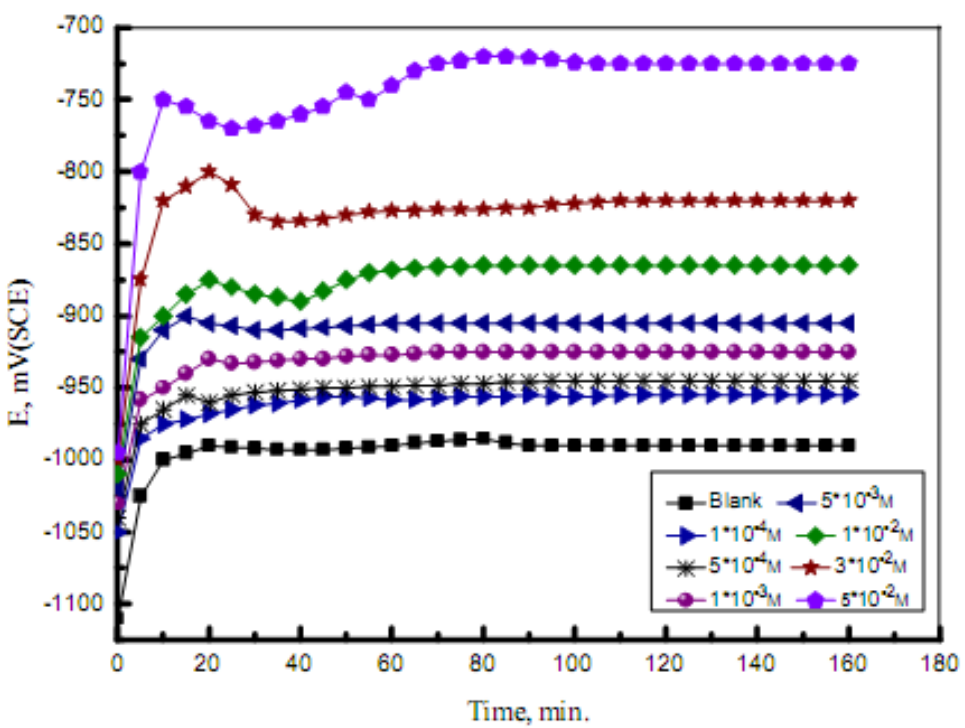

Fig. 11. The variation of zinc electrode potential, E, with time in solutions of $1 \times 10^{-3} \mathrm{M}$ $\mathrm{Na}_{3} \mathrm{PO}_{4} .12 \mathrm{H}_{2} \mathrm{O}+0.03 \mathrm{M} \mathrm{NaCl}$ in absence and presence of different concentrations of $\mathrm{Na}_{2} \mathrm{~B}_{4} \mathrm{O}_{7}$, at $25^{\circ} \mathrm{C}$.

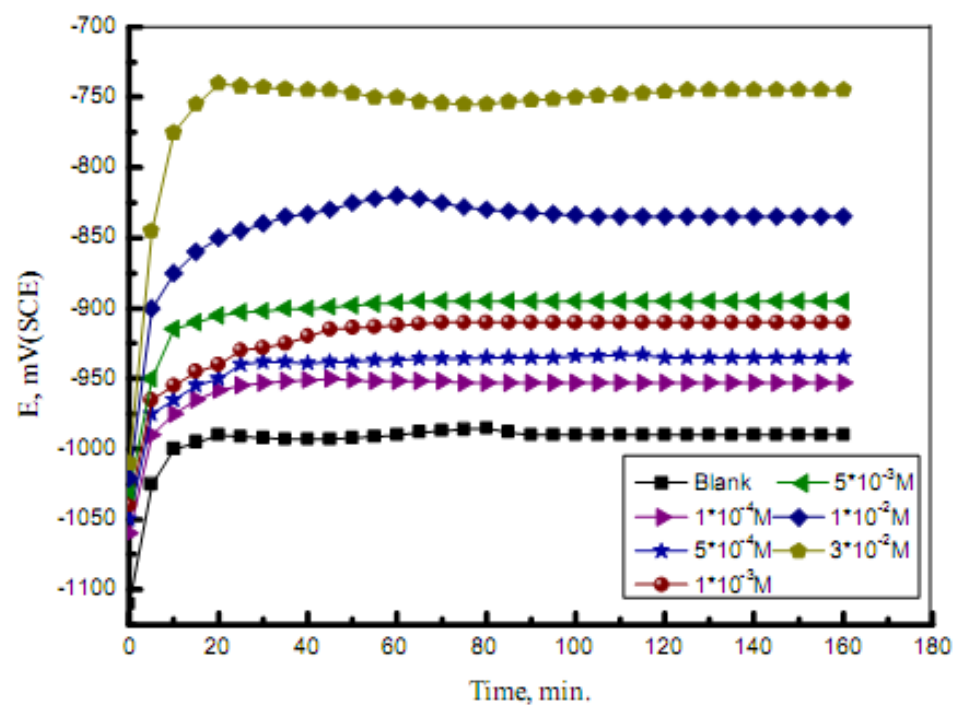

Fig. 12. The variation of zinc electrode potential, $E$, with time in solutions of $1 \times 10^{-3} \mathrm{M}$ $\mathrm{Na}_{3} \mathrm{PO}_{4} \cdot 12 \mathrm{H}_{2} \mathrm{O}+0.03 \mathrm{M} \mathrm{NaCl}$ in absence and presence of different concentrations of $\mathrm{Na}_{2} \mathrm{WO}_{4}$, at $25{ }^{\circ} \mathrm{C}$. 


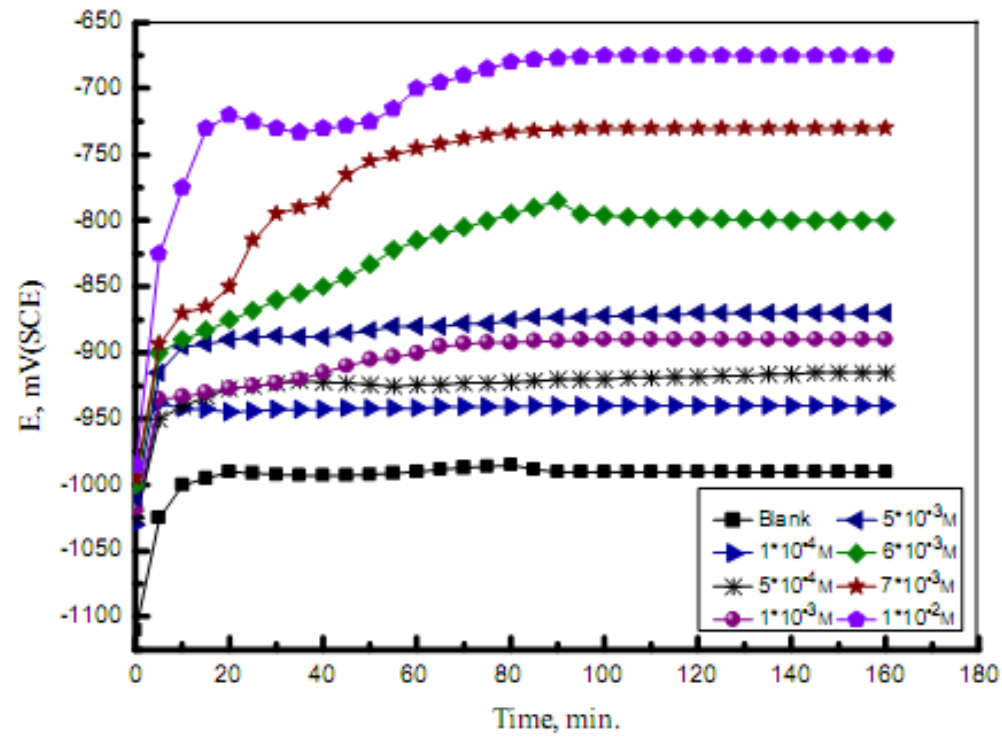

Fig. 13. The variation of zinc electrode potential, $E$, with time in solutions of $1 \times 10^{-3} \mathrm{M}$

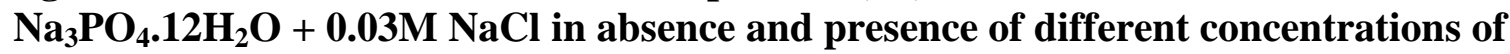
$\mathrm{Na}_{2} \mathrm{CrO}_{4}$, at $25^{\circ} \mathrm{C}$.

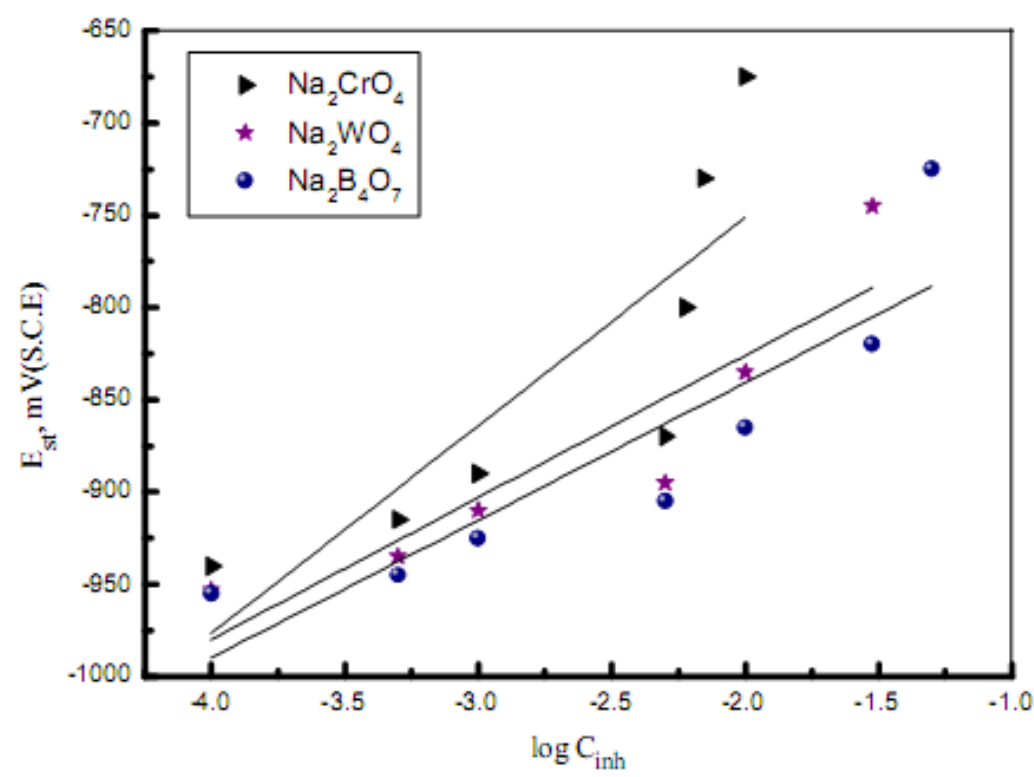

Fig. 14. Variation of steady state potential, $E_{s t}$ of zinc electrode with the logarithmic concentration of inorganic passivators in $1 \times 10^{-3} \mathrm{M} \mathrm{Na}_{3} \mathrm{PO}_{4} \cdot 12 \mathrm{H}_{2} \mathrm{O}+0.03 \mathrm{M} \mathrm{NaCl}$, at $25^{\circ} \mathrm{C}$. 